\title{
PRYWATYZACJA SZKOLNICTWA WYŻSZEGO W POLSCE I W EUROPIE ŚRODKOWO-WSCHODNIE) (1990-2020)
}

\section{Jadwiga Koralewicz*}

Abstrakt

Artykuł analizuje przemiany w prywatnym szkolnictwie wyższym w Polsce i Europie Środkowo-Wschodniej w latach 1990-2020. Po upadku komunizmu rozkwit prywatnego szkolnictwa był intensywny i gwałtowny. W Polsce prywatyzacja była szczególnie dynamiczna ze względu na wyż demograficzny, liczba studentów w ciągu pierwszych 15 lat wzrosła 5-krotnie. Artykuł ukazuje relacje między prywatnym i publicznym szkolnictwem wyższym. Od roku 2010 z przyczyn demograficznych zaczęła spadać liczba studentów i pojawiły się prognozy o upadku szkolnictwa prywatnego. Przewidywania te nie znajdują odzwierciedlenia w rzeczywistości, o czym świadczą dane empiryczne. Uczelnie prywatne bowiem odnalazły się w tej sytuacji.

Słowa kluczowe: prywatyzacja, szkolnictwo wyższe, uczelnie publiczne i niepubliczne, wyż demograficzny, niż demograficzny, uniwersytet, Europa Środkowo-Wschodnia

\section{Privatization of Higher Education Reforms in Poland AND IN CENTRAL AND EASTERN EUROPE}

\begin{abstract}
This article deals with the transformation of the previously non-existent private higher education in Poland and Central-Eastern Europe from 1990 to 2020. In Poland, moreover, privatization was particularly intense because of the increase in the country's population. The number of students increased fivefold in the first 15 years. The article describes the relationship between private and public higher education. From 2010 onwards, the number of students began to decline and predictions were made about the demise of private education. These predictions were incorrect. Private universities began, for example, to accept students from abroad and teach in English. Part-time students are now more likely to choose private universities than in the past. About $10 \%$ of these universities have become tertiary education institutions, whose students earn more after their studies than graduates of state universities.
\end{abstract}

Keywords: privatization, higher education, public and private universities, demographic growth, demographic decline, university, Central and Eastern Europe

Niniejszy tekst jest rozszerzoną wersją artykułu Privatization of Higher Education Reforms in Central and Eastern Europe - the Case of Poland. [w:] University Adaptation in Difficult Economic Times. (2014). (Ed.) Mattei P. Oxford-New York: Oxford University Press.

*Prof. dr hab. Jadwiga Koralewicz, Collegium Civitas, Warszawa, Polska

e-mail: jadwiga.koralewicz@civitas.edu.pl |ORCID: http://orcid.org/0000-0002-2014-5413 
Wstęp

Artykuł ten dotyczy dynamiki niepaństwowego - a w obecnej nomenklaturze niepublicznego ${ }^{1}$ - szkolnictwa wyższego w Polsce z perspektywy 30 lat. Z całkowitego niebytu w roku 1990 powstały uczelnie, które w latach 2006-2010 kształciły 30\% studentów. Przewidywania, że wraz z niżem demograficznym uczelnie te znikną, tak jak pojawiły się wraz z demograficznym wyżem, nie wydają się jednak trafne. Procesy społeczne i struktury instytucjonalne mają znacznie bardziej skomplikowaną dynamikę i zwykle nie są motywowane jednym czynnikiem. Zakorzenienie niepublicznych szkół wyższych w systemie społecznym, przy kontroli i konieczności podporządkowania się wielu regułom państwowym - głównie ministerialnym, ma jednak oparcie w systemie wolnorynkowym. Uczelnie te nie są subsydiowane z budżetu państwa.

Celem tego tekstu jest wskazanie określonych tendencji i istotnych problemów związanych z procesem prywatyzacji szkolnictwa wyższego na przestrzeni trzech dekad, nie zaś prześledzenie szczegółowych zmian, którym podlega niepubliczne szkolnictwo wyższe. Istnieje wiele raportów oraz danych ilościowych ilustrujących różne problemy tego sektora szkolnictwa wyższego, który pojawił się w okresie transformacji ustrojowej. Są one w tym artykule wykorzystane, ale swoją socjologiczną wiedzę konfrontuję także z praktyką, uczestnicząc od 23 lat w tworzeniu i funkcjonowaniu niepublicznej uczelni. Widzę różne problemy prywatyzacji od wewnątrz, na tym też polega znana w socjologii metoda obserwacji uczestniczącej. Ponadto w artykule tym przedstawiam prywatyzację szkolnictwa wyższego w Polsce na tle prywatyzacji tego sektora w krajach Europy Środkowo-Wschodniej (EW-S).

\footnotetext{
' Uwaga dotycząca terminologii. W latach 90. poprzedniego wieku istniały uczelnie państwowe i niepaństwowe. Obecnie stosuje się określenia uczelnie publiczne i niepubliczne (Ustawa 2018). Ponieważ niniejszy artykuł dotyczy procesu prywatyzacji szkolnictwa wyższego, czasem używam również określenia uczelnie prywatne. Tak więc nazwy: uczelnie niepaństwowe, niepubliczne i prywatne odnoszą się do tych samych podmiotów. Podobnie, określenia - uczelnie państwowe i publiczne - znaczą to samo. Po angielsku zwykle używa się pary określeń: private - state universities.
} 
Wyższe szkolnictwo prywatne w Europie Środkowo-Wschodniej na przełomie XX i XXI wieku

Prywatyzacja szkolnictwa wyższego w Europie Środkowo-Wschodniej po upadku komunizmu była procesem zupełnie nowym. Przed rokiem 1990 istniała w Polsce tylko jedna uczelnia mająca status uczelni prywatnej - Katolicki Uniwersytet Lubelski, który otrzymywał również dotacje państwowe. W Europie od XI wieku, kiedy powstał pierwszy uniwersytet w Bolonii, uniwersytety zwykle miały status uczelni publicznych. Niewątpliwie wspólnym dziedzictwem edukacji europejskiej jest istnienie dużych uniwersytetów, które tworzyły elity społeczne poszczególnych państw (Levy 2012).

Również w Europie Środkowo-Wschodniej (EŚ-W) znajdują się słynne uniwersytety, niektóre sięgające czasów średniowiecza, których kultura promieniuje na cały kraj i które od początku istnienia były finansowane przez państwo. W Europie Zachodniej studenci uczelni prywatnych stanowią jedynie 10\% ogółu studentów, w przeciwieństwie do uczelni amerykańskich (USA), gdzie istnieje znacznie większe zróżnicowanie pod względem statusu i finansowania instytucji edukacyjnych. Te, które są najbardziej znane i zajmują najwyższe miejsca w światowych rankingach są uczelniami prywatnymi, tak jak np. uniwersytety należące do elitarnej Ligii Bluszczowej (Ivy League). Najlepsze uczelnie na tych dwu kontynentach różnią się więc diametralnie swoimi właściwościami pod względem prawa własności, źródła finansowania, zakresu ingerencji państwa i wielu innych, ważnych dla ich funkcjonowania, czynników. Na szczycie światowych rankingów na obydwu kontynentach znajdują się zarówno prywatne, jak i państwowe instytucje szkolnictwa wyższego. Wprawdzie amerykańskie nie mogą sięgać średniowiecza, ale te najlepsze mają wielowiekową tradycję. Uniwersytet Harvarda liczy sobie już wiele setek lat, powstał bowiem w XVII wieku.

Ten historyczny wstęp jest jedynie tłem dla przedstawienia kilku, wydaje mi się ważnych, problemów prywatyzacji szkolnictwa wyższego 
w Europie Środkowo-Wschodniej. Prywatyzacji, która przybrała w tej części świata niespotykany dotąd rozmiar i intensywność.

Należy jednak zauważyć, że proces prywatyzacji uczelni nasilił się na całym świecie w ciągu kilku ostatnich dekad, szczególnie od lat 80. XX wieku. Wraz z prywatyzacją obserwuje się również wiele powiązanych ze sobą nowych procesów w szkolnictwie wyższym: umasowienie, globalizację, dywersyfikację, urynkowienie, nowy menedżeryzm, przedsiębiorczość, powiązanie studiów uniwersyteckich z biznesem itd. (Clark 1998; Deem 2001; Enterpreneurialism in universities and the knowledge economy 2008; Zakowicz 2013).

Postkomunistyczna prywatyzacja przebiegała w Europie ŚrodkowoWschodniej zazwyczaj w podobny sposób i napotykała na podobne problemy, jak w innych regionach świata, szczególnie w krajach rozwijających się. Powstało bowiem już wiele studiów porównawczych na ten temat (ASHE Higher Education Report 2010; Bjarnason at al. 2009; Levy 2006).

W XXI wieku do prywatnych uczelni przyjmowanych jest na całym świecie około 30\% studentów, co wskazali Philip G. Altbach, Liz Reisberg i Laura E. Rumbley (2009: XIV). Autorzy ci w swoim podsumowaniu wyników Światowej Konferencji UNESCO poświęconej szkolnictwu wyższemu piszą, że w ciągu 7 lat (2000-2007) liczba studentów na świecie wzrosła o 7 punktów procentowych, z 19 do 26\% (Ibidem: VI). Największy ich przyrost wśród wszystkich regionów świata odnotowano w tym czasie w Europie Środkowo-Wschodniej: z 40 do 61\% (Ibidem: VII, Figure I). Badacze zwracają także uwagę na gwałtowny przyrost prywatnych uczelni, który nastąpił głównie w Centralnej i Wschodniej Europie i w krajach byłego Związku Radzieckiego.

Rozwój sektora prywatnego i częściowa prywatyzacja sektora publicznego (płatne studia wieczorowe, weekendowe oraz studia podyplomowe), odegrały szczególnie widoczną rolę w takich krajach, jak Polska, Rumunia, Gruzja, Estonia i Łotwa. Voldemar Tomusk (2003) porównał 
efekty prywatyzacji szkolnictwa wyższego w krajach EŚ-W w czasach postkomunistycznych do rewolucji.

Rozwój niepublicznego segmentu edukacji wyższej nie był równomierny we wszystkich państwach EŚ-W. Na przełomie XX i XXI wieku różnice między tymi państwami były znaczące: uczelnie prywatne w Chorwacji lub na Słowacji przyjmowały zaledwie od 3,o do 4,6\% ogółu studentów w tych państwach, podczas gdy uczelnie prywatne w Estonii, Polsce i Rumunii przyjmowały niemal jedną trzecią wszystkich studentów. W innych państwach, takich jak Bułgaria, Węgry i Rosja, liczba studentów na niepublicznych uczelniach wynosiła około 15\% (dane z tekstów różnych autorów zawartych w: Private higher education in postcommunist Europe 2007).

Ponadto analiza porównawcza procesu prywatyzacji w tej części Europy wskazuje na podobieństwa do innych regionów, takich jak Azja, Afryka i Ameryka Południowa, w których liczba studentów uległa również dynamicznemu wzrostowi (Jamshidi et al. 2012; Mok 2009; Rabossi 2011; Welch 2007).

Tendencja ta jest słabiej widoczna w szkolnictwie wyższym w Europie Zachodniej, gdzie prywatyzacja wciąż, zgodnie z wielowiekową tradycją, nie odgrywa istotnej roli (Levy 2012). W krajach EŚ-W to zróżnicowanie, czyli podział na uczelnie prywatne i państwowe był szybki i wyraźny, chociaż różnił się w zależności od państwa. Różnice te dotyczą struktury organizacyjnej, misji, założycieli, a także proporcji istnienia instytucji niekomercyjnych i komercyjnych.

W niektórych państwach EŚ-W uczelnie prywatne naśladują misję i strukturę uczelni publicznych, podczas gdy w innych, odrębne cele i struktury są wyznaczane jedynie dla instytucji prywatnych, co często sprawia, że różnią się one nie tylko od instytucji publicznych, ale także między sobą. Na przykład w Rumunii uczelnie prywatne kopiowały strukturę i misję uczelni publicznych, tym samym szybko zwiększając swój udział w sektorze edukacji (Nicolescu 2007). W Polsce uczelnie 
prywatne starały się różnić od uczelni publicznych, szczególnie w zakresie struktury, misji i programów nauczania (Duchmal 2006).

Państwa różnią się miedzy sobą w zakresie wpływu rządu na funkcjonowanie instytucji szkolnictwa wyższego i ich kontrolę. W czeskich programach rządowych określono szczegółowe zasady funkcjonowania uczelni prywatnych, a rząd podobno nadal ściśle ich przestrzega. Tymczasem w Polsce państwo przyjęło podejście liberalne, pozostawiając duży margines swobody w zakresie działania placówek prywatnych. Duże zróżnicowanie w regionie można zaobserwować w zasadach przyznawania akredytacji: od całkowitego braku wymogu akredytacji dla uczelni prywatnych, poprzez wymóg ubiegania się o akredytację po kilku latach funkcjonowania, aż po rygorystyczne zasady przyznawania akredytacji na podstawie tych samych kryteriów, mających zastosowanie do instytucji publicznych. Państwa EŚ-W różnią się także w polityce podatkowej wobec uczelni prywatnych, chociaż w większości uznawane są jako instytucje niekomercyjne.

Warto również wspomnieć, że państwowe i prywatne instytucje szkolnictwa wyższego mają prawo łączyć się w niektórych krajach. Większość państw rozróżnia te dwa rodzaje instytucji ze względu na typ własności i podstawy prawnej działalności, jak również odmienne źródła finansowania. Niemniej jednak np. w Rosji istnieją przypadki tworzenia uczelni niepublicznych przez uczelnie publiczne (Suspitsin 2005).

Warto także wspomnieć o odmiennych formach państwowej pomocy finansowej udzielanej prywatnym placówkom szkolnictwa wyższego w postaci stypendiów, funduszy na utrzymanie infrastruktury lub środków na działalność statutową. Poszczególne kraje EŚ-W różniły się również wielkością miejscowości, w których powstawały prywatne uczelnie. W Polsce były one zakładane również w wielu mniejszych miejscowościach, podczas gdy na przykład w Republice Czeskiej były skupione głównie w Pradze, a poza stolicą powstało ich niewiele (Bajerski 
2007). Autor ten również zauważa, że w Republice Czeskiej prywatyzacja szkolnictwa wyższego zaczęła się dość późno, w roku 1998, i była solidnie przygotowana, szczególnie w zakresie procedury akredytacyjnej.

Niestety w Polsce i w kilku innych krajach Europy ŚrodkowoWschodniej uczelnie niepubliczne, które zaczęły powstawać na początku lat 90. zeszłego wieku, nie musiały spełniać wielu ustaleń prawnych. Odbiło się to, z jednej strony na jakości kształcenia oraz na niskiej reputacji wielu uczelni, a także, co za tym idzie, na zgeneralizowanej złej opinii o całym prywatnym szkolnictwie wyższym. Wspomniany wcześniej autor tekstu o szkolnictwie prywatnym w Republice Czeskiej stwierdza, że ten rodzaj szkolnictwa wyższego cieszy się tam dobrą reputacją. W wielu tych uczelniach od początku nauczano w języku angielskim (Ibidem).

W państwach EŚ-W obserwuje się często brak legitymizacji prywatnego szkolnictwa wyższego. Wśród znacznej części społeczeństwa w tych krajach wciąż dominuje opinia, że to państwo a nie rynek powinno zarządzać całym sektorem szkolnictwa wyższego (Private higher education in post-communist Europe 2007). Tymczasem to właśnie sektor prywatny zaspokaja popyt na edukację wyższą i wypełnia lukę powstałą w wyniku zbyt niskiego finansowania edukacji wyższej przez państwo i braku miejsc w uczelniach publicznych. Opłaty i czesne wnoszone przez studentów oraz brak znaczącego wsparcia finansowego przez budżet państwa są wspólnymi cechami prywatnego szkolnictwa wyższego na świecie, nie tylko w krajach EŚ-W (Private higher education: A global revolution 2005; Scott 2007; Kinser at al. 2010).

Kolejną wspólną cechą uczelni prywatnych w regionie EŚ-W jest ograniczony udział w badaniach naukowych, ponieważ ich działalność jest ukierunkowana głównie na edukację. Zatrudnianie wykładowców publicznych uczelni z powodu braku własnej kadry profesorskiej jest kolejnym wspólnym mianownikiem uczelni prywatnych w różnych krajach EŚ-W (Pachuashvili 2009). 
Prywatyzacja szkolnictwa wyższego w Polsce w XX i XXI wieku

Kolejna część tego artykułu dotyczy tylko Polski. To właśnie tu szkolnictwo niepubliczne najbardziej zmieniło oblicze szkolnictwa wyższego wśród wszystkich krajów EŚ-W. Wśród nowoprzyjętych wówczas studentów, w uczelniach publicznych (na studia weekendowe, wieczorowe i podyplomowe) oraz w uczelniach niepublicznych - 60\% płaciło za edukację (Strategia Rozwoju Szkolnictwa Wyższego w Polsce do 2020 roku 2010: 28). Co oznacza, że konstytucyjne prawo wszystkich obywateli do bezpłatnej nauki w Polsce jest fikcją.

W ciągu 15 lat (1990-2005) liczba wszystkich studentów wzrosła pięciokrotnie (patrz tabela 1). Z kraju o niskim poziomie wykształcenia w Europie (w roku 1988 jedynie 6,5\% społeczeństwa posiadało wykształcenie wyższe), w roku 2005 Polska stała się państwem, w którym wskaźnik skolaryzacji dorównał średniej krajów zrzeszonych w Organizacji Współpracy Gospodarczej i Rozwoju (Organization for Economic Co-operation and Development, OECD). Był to najwyższy wynik w regionie EŚ-W i wyższy niż w wielu państwach Europy Zachodniej (Edquist et al. 2007: 35).

Tabela 1. Liczba studentów w Polsce w latach 1990-2010 w podziale na uczelnie publiczne i niepubliczne oraz na studia stacjonarne i niestacjonarne

\begin{tabular}{lllll}
\hline \multirow{2}{*}{$\begin{array}{l}\text { Rok } \\
\text { akademicki }\end{array}$} & \multicolumn{2}{l}{ Uczelnie publiczne } & \multicolumn{2}{l}{ Uczelnie niepubliczne } \\
\cline { 2 - 5 } & $\begin{array}{l}\text { Studia } \\
\text { stacjonarne }\end{array}$ & $\begin{array}{l}\text { Studia } \\
\text { niestacjonarne }\end{array}$ & $\begin{array}{l}\text { Studia } \\
\text { stacjonarne }\end{array}$ & $\begin{array}{l}\text { Studia } \\
\text { niestacjonarne }\end{array}$ \\
\hline $\mathbf{1 9 9 0 / 9 1}$ & 299000 & 91000 & - & - \\
\hline $\mathbf{1 9 9 5 / 9 6}$ & 425000 & 233000 & 19000 & 20000 \\
\hline $\mathbf{2 0 0 0 / 0 1}$ & 603000 & 529000 & 91000 & 318000 \\
\hline $\mathbf{2 0 0 5 / 0 6}$ & 817000 & 539000 & 133000 & 434000 \\
\hline $\mathbf{2 0 1 0 / 1 1}$ & 870000 & 415000 & 79000 & 516000 \\
\hline
\end{tabular}

Źródło: MNiSW 2013: 6. 
Wielu autorów zajmujących się w swoich badaniach szkolnictwem wyższym zauważa, że prywatyzacja w Polsce, ale także w innych krajach, ma dwa oblicza: tworzenie uczelni niepublicznych w sektorze szkolnictwa wyższego oraz komercjalizację szkolnictwa w systemie edukacji publicznej (Geiger 1986; Levy 1986).

Proces ten będzie w dalszej części tego artykułu analizowany między innymi także za pomocą metody socjologicznej zwanej obserwacją uczestniczącą. Jestem socjologiem, ale od 23 lat uczestniczę także w procesie tworzenia i zarządzania uczelnią niepubliczną. Prace na temat przemian systemu szkolnictwa wyższego w Polsce i w Europie Środkowo-Wschodniej przedstawiają najczęściej punkt widzenia specjalistów do spraw polityki naukowej. Tak zwane podejście instytucjonalne dotyczące szkolnictwa wyższego w Polsce zostało zaprezentowane między innymi w pracach autorów, do których odwołuję się w tym artykule - Dominika Antonowicza i Bartłomieja Gorlewskiego (2011), Wojciecha Duchmala (2006) czy Marka Kwieka (2009; 2011; 2015). Podobnie instytucjonalny punkt widzenia dotyczący całego regionu EŚ-W przedstawiają między innymi Voldemar Tomusk (2003), Peter Scott (2007) czy praca Private higher education in post-communist Europe (2007).

Wojciech Duchmal (2006) cierpko zauważył, że temat prywatyzacji szkolnictwa wyższego w Polsce nie został dobrze zbadany. W znacznym stopniu, opinia ta dotyczy także lat obecnych. Rzeczywiście mało jest badań empirycznych na ten temat, a szczególnie pogłębionych badań na próbach reprezentatywnych.

Chciałabym zwrócić jednak uwagę na dwie prace, które stanowiły pierwotnie rozprawy doktorskie. Prezentują one ciekawe wyniki badań przeprowadzonych w Polsce i dotyczących polskiego szkolnictwa wyższego. Jedna została napisana w Stanach Zjednoczonych (Musiał 2012), druga w Polsce (Zawistowska 2012).

Istnieją też liczne sprawozdania i analizy sporządzone na podstawie dostępnych danych statystycznych, które zostały w prawidłowy sposób przetworzone i porównane oraz które zawierają wiele interesujących 
hipotez, jak również szereg ogólnych lub szczegółowych stwierdzeń (np. sprawozdania i raporty sporządzone na zlecenie OECD (Edquist et al. 2007) czy Banku Światowego (World Bank 2004).

Ostatnio ukazał się także raport zawierający wiele pogłębionych analiz dotyczących szkolnictwa wyższego w Polsce w latach 2012-2018 przygotowany przez Ośrodek Przetwarzania Informacji - Państwowy Instytut Badawczy (2019). Raport ten uwzględnia podział szkolnictwa wyższego na publiczne i niepubliczne.

Po okresie 30 lat dynamika, znaczenie i wartość procesu prywatyzacji szkolnictwa wyższego w Polsce wydają się wyraźnie widoczne. Proces ten został zepchnięty na dalszy plan przez wiele agend społecznych, jego znaczenie zostało umniejszone i czasem napiętnowane (szczególnie przez lobby dużych uniwersytetów). Z historycznej perspektywy tego procesu, porównując go z innymi państwami regionu EŚ-W i z całą Europą oraz z innymi regionami spoza kontynentu, widoczne staje się społeczne znaczenie procesu prywatyzacji polskiego szkolnictwa wyższego oraz jego wpływ na transformację tego całego sektora w Polsce (Wells, Sadlak, Vlasceanu 2007).

Nie tylko w uczelniach prywatnych

Socjologowie i psychologowie społeczni podkreślają, że wpływ wykształcenia wyższego jest widoczny w zmianie nastawienia i perspektywy poznawczej jednostek oraz grup społecznych w kierunku otwartości na różnorodność, mniejszą stronniczość i tolerancję, większą pewność siebie i większy optymizm.

Edukacja (publiczna i niepubliczna) jest również ważną wartością społeczną. Społeczeństwo oparte na wiedzy i gospodarka oparta na wiedzy wymaga właściwej infrastruktury badawczej i edukacyjnej oraz kształcenia opartego na określonych programach.

Edukacja społeczeństwa ma jednak również skutek kulturowo-cywilizacyjny, który należy koniecznie uwzględnić, przedstawiając zjawisko 
pięciokrotnego wzrostu liczby studentów w Polsce. Oprócz innych skutków procesu transformacji w Polsce jest to efekt, który profesor Leszek Balcerowicz (2002) określił jako największe osiągnięcie rozwoju postkomunistycznej Polski.

Podział edukacji na publiczną i niepubliczną oraz relacje między tymi dwoma sektorami przyćmiły znaczenie wielu innych trwających, ale ignorowanych procesów. Także braku wielu istotnych zmian, które były potrzebne, ale zostały zaniechane w polskim szkolnictwie wyższym, takich jak np. związek między kształceniem i prowadzeniem badań naukowych, szybszym osiąganiem doktoratów i habilitacji przez nauczycieli akademickich, udziału w międzynarodowych badaniach naukowych.

Innym problemem jest wewnętrzne zróżnicowanie jakościowe w obydwu sektorach, które zazwyczaj nie jest uwypuklane, chociaż oczywiście ma miejsce. Nie chodzi tylko o to, że zarówno wśród uczelni publicznych, jak i niepublicznych istnieją lepsze i gorsze uczelnie, ale również o to, że w ramach jednej uczelni znajdują się wydziały posiadające różne osiągnięcia dydaktyczne i naukowe, zatrudniające bardziej lub mniej kompetentną kadrę.

Rola badań naukowych została w wielu uczelniach państwowych zmarginalizowana, o czym często wspomina się w różnych międzynarodowych sprawozdaniach dotyczących nauki w Polsce i co znajduje odzwierciedlenie w wynikach międzynarodowych rankingów, w których badania są kluczowym wskaźnikiem pozycji danej uczelni (dwie najlepsze polskie uczelnie, Uniwersytet Warszawski i Uniwersytet Jagielloński, znajdują się w czwartej setce rankingu szanghajskiego). Jak pisze Marek Kwiek (2015: 138), „Podobnie jak w innych częściach naszego regionu, także w Polsce badania są prowadzone jedynie w najlepszych instytucjach publicznych (...). Sektor prywatny - ze związanej z prestiżem perspektywy badań naukowych - w zasadzie nie istnieje (...)”.

Niewiele się ciągle mówi o bardzo niskim procencie PKB, które w Polsce przeznacza się na szkolnictwo wyższe (ciągle oscylujemy wokół 1\%) oraz o relatywnie niewielkim budżecie przeznaczanym na badania 
w instytucjach akademickich w porównaniu do innych krajów europejskich.

Ciągle jest niewielka liczba grantów przyznawanych w ramach europejskich konkursów dla polskich naukowców i polskich zespołów badawczych. Wzrost liczby absolwentów studiów doktoranckich jest również stosunkowo niski, także podwyższanie kwalifikacji wykładowców zachodzi stosunkowo powoli. W pierwszej dekadzie XXI wieku aż 43,2\% wykładowców polskich uniwersytetów w ciągu trzech lat nie opublikowało żadnej pracy naukowej (Ibidem: 389).

Wzrost liczby studentów wynika głównie z tego, że w latach 90. zeszłego wieku znaczna część społeczeństwa postanowiła zainwestować w edukację swoich dzieci lub poprawę własnej edukacji (na studiach niestacjonarnych). W roku 2000/2001 za studia płaciło 938 tys. studiujących osób (studenci uczelni niepublicznych oraz niestacjonarni studenci uczelni publicznych), a 603 tys. nie płaciło (patrz tabela 1). Odzwierciedla to zatem inwestycję osób prywatnych, które oprócz płacenia podatków (finansujących edukację publiczną) zdecydowały na różnych etapach życia swojego i swoich dzieci, że jest to logiczna inwestycja, czyli taka, która odpowiada ich systemom wartości, aspiracjom i osobistym celom, a jej korzyści są możliwe do osiągnięcia i warte nakładów.

Wartość edukacji i oczekiwanie sprawiedliwości merytokratycznej można zaobserwować w polskim społeczeństwie w badaniach socjologicznych prowadzonych już od lat 6o. XX wieku (Koralewicz, Ziółkowski 2006). Edukacja miała wówczas wyższą wartość niż pieniądze. Stanowiła ona zarówno wartość autoteliczną, jak i instrumentalną we wszystkich klasach społecznych, o różnych dochodach, poziomie wykształcenia i rodzaju wykonywanego zawodu. Dostęp do edukacji był jednak ograniczony ze względu na niewystarczającą liczbę miejsc w uczelniach, ale również dlatego, że znajdowały się one tylko w dużych miastach. Stanowiło to barierę finansową dla mniej zamożnych grup społecznych. $Z$ drugiej strony, dzieci ze środowisk robotniczych i wiejskich mogły otrzymać dodatkowe punkty 
na egzaminach, co z kolei zmniejszało szanse przyjęcia na studia młodych ludzi z warstwy inteligenckiej.

Lata 70. i 80. XX wieku w Polsce były okresem kryzysu gospodarczego. W tym czasie badania socjologiczne ukazywały coraz mniejszą zależność między wykształceniem, a materialnym poziomem życia. Czynniki inne niż wykształcenie decydowały o możliwościach zawodowych i osiągnięciu pożądanego statusu społecznego: podporządkowanie się kierownictwu partii, działalność w szarej strefie, powiązania osobiste, umiejętność omijania prawa (Koralewicz, Ziółkowski 2003).

W wielu dziedzinach życia, także w zakresie aspiracji zdobycia wyższego wykształcenia, większość społeczeństwa pozostawała w stanie względnej deprywacji. Transformacja rozpoczęta w Polsce w roku 1989 odblokowała przez długi czas niezaspokajane potrzeby związane z edukacją. Należy również wspomnieć o aspekcie demograficznym, który być może odegrał największą rolę. Lata 90. XX wieku to czas, w którym duża część młodych ludzi w Polsce osiągnęła wiek akademicki.

W drugiej połowie lat 8o., w trakcie istnienia w sposób legalny pierwszej „Solidarności” (1980-1981) i w okresie stanu wojennego wprowadzonego 13 grudnia 1981 roku, urodziło się szczególnie dużo dzieci w Polsce. W latach 90. o jedno miejsce na studia ubiegało się 6-8 absolwentów szkół średnich. Wiele z tych osób, które wcześniej nie ukończyły studiów z powodu podjęcia pracy, zamierzało nadrobić zaległości w trybie weekendowych studiów niestacjonarnych. W zmieniającej się, prywatyzującej i otwierającej się na świat gospodarce rosło zapotrzebowanie rynku pracy na absolwentów szkół wyższych. Wówczas to narodził się rynek edukacyjny.

Rozwój prywatnego szkolnictwa wyższego. Relacje z uczelniami publicznymi

Nowelizacja ustawy o szkolnictwie wyższym z roku 1990 wprowadziła możliwości kształcenia w uczelniach niepaństwowych (Ustawa 1990). Utworzony został sektor edukacji prywatnej, w którym studenci płacili 
zarówno za studia stacjonarne, jak i niestacjonarne. Publiczne studia stacjonarne były bezpłatne, ale miejsc dla kandydatów 5-6 razy za mało. Uczelnie publiczne zwiększyły liczbę miejsc na płatnych studiach wieczorowych i zaocznych. Profesor Marek Kwiek opisał ten proces jako zewnętrzną i wewnętrzną prywatyzację szkolnictwa wyższego w Polsce (2011). Egzamin konkursowy decydujący o przyjęciu na bezpłatne studia oczywiście dobrze zdawali ci, którzy byli lepiej przygotowani.

Uczelnie prywatne stanowiły opcje alternatywne, jak trafnie nazwała je Joanna Musiał (2012). Inna autorka opracowania na temat nierówności horyzontalnych w polskim systemie edukacji stwierdziła, że kandydaci, których dwoje rodziców miało wykształcenie wyższe, byli częściej przyjmowani na prestiżowe bezpłatne uczelnie publiczne na wydziały wymagające dłuższego okresu studiów (Zawistowska 2012).

Kapitał kulturowy odgrywał ważną rolę w rekrutacji na bezpłatne studia na te uczelnie. Struktura społeczna była odtwarzana poprzez akumulację kapitału kulturowego (Bourdieu, Passeron 1990). Młodzi ludzie o mniejszym kapitale kulturowym godzili płatne studia na uczelniach prywatnych z zatrudnieniem lub uczęszczali na równie płatne studia wieczorowe i weekendowe w uczelniach państwowych. Do prywatnych wyższych uczelni uczęszczało i uczęszcza wiele młodych osób, które już wcześniej były zatrudnione. Jednak ich wiedza specjalistyczna w danej dziedzinie była znaczenie większa niż w przypadku studentów bezpłatnych studiów dziennych.

Zainteresowanie wszystkich studentów kursami oferującymi zajęcia praktyczne pozwoliło natomiast pracującym studentom uzupełnić już posiadane umiejętności wiedzą teoretyczną. Uczelnie prywatne wychodziły więc naprzeciw wymaganiom potencjalnych studentów, oferując zarówno zajęcia praktyczne, jak i teoretyczne. Uczelnie prywatne były mniejsze, elastyczniej zarządzane, szybsze w podejmowaniu decyzji, a co za tym idzie, szybsze w uruchamianiu nowych programów i kursów. Ponadto były w stanie zatrudniać ekspertów posiadających znaczną wiedzę specjalistyczną i ugruntowaną pozycję zawodową. Wielu z nich 
posiadało stopień doktora, więc również w tym zakresie uczelnie prywatne spełniały wymagania rynku pracy.

Uczelnie prywatne miały w swojej ofercie także liczne niestacjonarne studia podyplomowe, na ogół trwające jeden rok i w większości będące kursami kwalifikacyjnymi (np. umożliwiającymi prawnikom zdobycie nowych specjalistycznych kwalifikacji), a jako takie odgrywały ważną rolę w systemie kształcenia przez całe życie. Prowadziły kursy dla kandydatów w wieku powyżej 40 lub 50 lat. Były również szybsze niż uczelnie państwowe w podejmowaniu współpracy z różnymi sektorami biznesu. Niektóre przedsiębiorstwa fundowały stypendia studentom uczącym się na wybranych kierunkach. Przedsiębiorstwa zamawiały kursy dostosowane do potrzeb swoich pracowników, zawierały umowy określające odpowiednie treści programowe, a także współpracowały przy tworzeniu programów stażu zawodowego dla studentów.

Uczelnie prywatne były pierwszymi, które wprowadziły szeroko zakrojone programy studiów w języku angielskim - jako głównym językiem wykładowym. W latach 90. XX wieku nieliczne uczelnie państwowe prowadziły programy w języku angielskim jako głównym języku wykładowym (z wyjątkiem kilku wydziałów uczelni państwowych). W porównaniu z sektorem państwowym uczelnie prywatne jako pierwsze skierowały swoją ofertę do zagranicznych studentów. Liczba studentów z zagranicy uległa znaczącemu i szybkiemu wzrostowi właśnie w uczelniach prywatnych.

Ogólnie rzecz biorąc, wydaje się, że uczelnie prywatne były w latach 90. również lepiej od państwowych zarządzane. Zatrudniały specjalistów do spraw zarządzenia edukacją i zapewniały studentom lepszą obsługę administracyjną. Wprowadziły jako pierwsze system komunikacji przez Internet: wykładowca-student oraz student-administracja uczelni, na kilka lat wcześniej przed tym, zanim stało się to normą w państwowym szkolnictwie wyższym. Jednak oba typy uczelni wyższych - publiczne i prywatne - niewiele się zmieniły pod względem formy nauczania. Przez wiele lat, szczególnie jeszcze w latach 90. ubiegłego wieku, proces 
nauczania polegał głownie na wykładach i zajęciach prowadzonych dla dużych grup biernie uczestniczących studentów, zaś kontakty między nauczycielami akademickimi a studentami były nadal znacząco sformalizowane.

Proces kształcenia w Polsce, również przez wiele lat transformacji, nie rozwijał takich cech, jak umiejętność analitycznego, kreatywnego czy strategicznego myślenia, rozwiązywania problemów oraz współpracy grupowej. Polska młodzież nie kształci tego także w większości szkół licealnych, nie wspominając o niższych poziomach szkolnictwa. Ciągle pierwsze miejsce zajmują fakty i ćwiczenie pamięci.

Uczelnie prywatne znacznie wcześniej niż państwowe wprowadziły nowe formy zajęć: warsztaty, gry strategiczne oraz zajęcia mające na celu rozwój umiejętności interpersonalnych studentów. Jednak te formy nauczania były w latach 90. zeszłego wieku inicjowane głównie przez niewiele najlepszych uczelni prywatnych i raczej są przeznaczone dla studentów uczących się w małych grupach w systemie stacjonarnym. Studenci ci stanowili i nadal stanowią niewielki odsetek studentów uczelni prywatnych. Osoby uczące się w trybie niestacjonarnym (weekendowym), które muszą płacić za swoją edukację zarówno w sektorze państwowym, jak i prywatnym, coraz chętniej wybierają uczelnie sektora prywatnego (porównaj dane z tabeli 1 i 2).

Uczelnie publiczne o ugruntowanej pozycji, mimo że przez wiele lat nie dokonywały zasadniczych zmian, szczególnie w latach 90. XX wieku i w pierwszej dekadzie XXI, wybierane były i są przez dzieci osób z wyższym wykształceniem, z wyższym dochodem i z większych miast (Zawistowska 2012). Polska tradycja szkolnictwa państwowego (nieobecność uczelni prywatnych w okresie komunizmu), wysoki prestiż, jaki posiadały uczelnie państwowe oraz tradycyjnie elitarna renoma szkolnictwa wyższego w Polsce sprawiały, że uczelnie prywatne (jak wspomniano powyżej) stanowiły opcję alternatywną, były i są szkołami drugiego wyboru. Utalentowani i ambitni młodzi ludzie najpierw starali się o przyjęcie na studia w uczelni państwowej i to nie tylko z powodu braku opłat za studia. 
Szkolnictwo prywatne w Polsce istnieje, od samego początku do tej pory, dzięki opłatom studentów, głównie w postaci czesnego. Pewne inicjatywy założycielskie były wzmacniane finansowo przez instytucje i organizacje zagraniczne bądź samorządy lokalne oraz inne organizacje w Polsce. Codzienne utrzymanie uczelni opiera się już jednak na czesnym od studentów. Uczelnie starają się zatem głównie o ich dużą liczbę.

O ile na rynku byli i są kandydaci na studia, to znacznie gorzej przedstawiał się problem z liczbą dostępnych wykładowców. W latach 90. XX wieku nie było na rynku pracy dostatecznie wielu wykładowców, którzy mogliby stanowić stałą kadrę dla 200 nowych uczelni, które powstały w ciągu 10 lat. Nie dysponuję szczegółowymi danymi, ale odwołam się do opinii wybitnych specjalistów w dziedzinie badań nad szkolnictwem wyższym w Polsce.

Marek Kwiek pisze: „Instytucje sektora prywatnego (...) działały w większości przypadków jak duże spółki edukacyjne typu for profit, zatrudniające kadrę wywodzącą się przede wszystkim z publicznych instytucji edukacyjnych" (Kwiek 2015: 108). Ireneusz Białecki stwierdził w roku 2008: „Zatrudnienie w szkołach prywatnych na drugim etacie pracowników dydaktycznych szkół publicznych, zwłaszcza w początkowym okresie (lata dziewięćdziesiąte), było względnie łatwe i tanie w przypadku nauk społecznych i ekonomicznych" (Białecki 2008: 31).

Był jednak pewien zasób kadry naukowej, który mógłby zasilić powstające uczelnie prywatne. To naukowcy Polskiej Akademii Nauk, którzy już czasem pełnili funkcje dydaktyczne, ale głównie na poziomie studiów doktoranckich w macierzystych instytutach PAN. Ówczesne zasady prawne, które nie zostały dotąd zmienione, nie pozwalały na tworzenie szkół wyższych stowarzyszonych formalnie z jednym czy z kilkoma instytutami PAN. W latach 90. XX wieku powstało kilka uczelni prywatnych (tylko ten status był prawnie możliwy), których program był przygotowany w instytutach PAN-owskich. Pracownicy naukowi tych instytutów mieli uczyć studentów przedmiotów, w których byli często światowej klasy specjalistami. 
Była też propozycja stworzenia uczelni PAN-owskiej z programem studiów licencjackich i magisterskich, lecz nigdy do tego nie doszło. Prezes PAN, prof. Leszek Kuźnicki w roku 1997 podczas jednej z uczelni stworzonej przez profesorów PAN powiedział: „To już siódma wyższa uczelnia, która powstaje przy placówkach Polskiej Akademii Nauk” (cytat za: Koralewicz 2012: 20).

Do koncepcji uczelni PAN-owskiej powrócono kilka lat temu, już z propozycją studiów na poziomie doktorskim. Powstała bardzo dobra, szczegółowo opracowana koncepcja. Jednak dotąd pozostaje niezrealizowana (Duszyński, Burczyński, Rowiński, Rychard 2017).

Jaka była szansa istnienia dobrych uczelni prywatnych bez własnej kadry naukowej? Czy mogły powstać dobre, prestiżowe instytucje kształcenia studentów, utrzymujące się jedynie z czesnego, od których oczekuje się także prowadzenia własnych badań? Instytucje prywatne konkurują o studentów z państwowymi uczelniami, które otrzymują dotacje od państwa i wydają na kształcenie jednego studenta sumę 100\% większą niż w szkołach prywatnych. Studenci państwowych uczelni na dziennych studiach nie płacą czesnego, szkoły te mają ustabilizowaną od kilkudziesięciu lat kadrą naukową oraz czasem także wielowiekową tradycję.

Mimo tego uczelnie prywatne stanowiły znaczącą siłę napędową dla szybszych zmian w szkolnictwie wyższym oraz w jakimś zakresie przyczyniły się do modernizacji uczelni państwowych za sprawą mechanizmu konkurencji (oczywiście nie neguję wpływu innych czynników zmian szkolnictwa publicznego). Jednak do roku 2019 zmiany te następowały dość wolno i były słabo widoczne. Znaczna liczba uczelni i ich wydziałów pracowała w starym paradygmacie z początku lat 90. XX wieku, mimo kilku prób zmian Ministerstwa Nauki i Szkolnictwa Wyższego (MNiSW). Być może program reformy 2.0 odwróci ten utrwalony trend i pozwoli publicznym uczelniom bardziej się zbliżyć do poziomu dobrych europejskich uczelni publicznych. 
Wpływ niżu demograficznego na szkolnictwo wyższe

Zgodnie z przewidywaniami w połowie pierwszego dziesięciolecia XXI wieku rozpoczął się znaczący dla szkolnictwa wyższego niż demograficzny. W roku 2006 po okresie systematycznego wzrostu zaczęła się zmniejszać w Polsce liczba młodych ludzi w wieku 19-24 lat. Liczba 19latków zmniejszała się już od roku 2003, gdy było ich 3944,9 tys., natomiast w roku 2013 - już jedynie 3074,4 tys. (GUS 2020a).

Zapoczątkowana wówczas tendencja demograficzna trwa do dzisiaj, czyli do końca roku 2020 i trwać ma jeszcze wiele lat.

Od roku 2009 zaczęła się zmniejszać liczba studentów uczelni niepublicznych, w 2013 roku było ich 62,4\% w stosunku do roku 2006 (100\%) (patrz tabela 1).

W końcu roku 2020 liczba prywatnych uczelni wynosiła jednak 225 wciąż istniejących jednostek. W latach 1991-2020 powstało w Polsce 375 uczelni. W ciągu 30 lat zostało zamkniętych lub pozostaje obecnie w stanie likwidacji 150 uczelni prywatnych (MEiN 2020). Nie spełniają się więc przewidywania poczynione 5 lat temu o stopniowym zaniku sektora prywatnego w szkolnictwie wyższym.

MNiSW przedstawiło prognozę na rok 2022 (za: Kwiek 2015: 130132), w której przewiduje się, że w roku tym pozostanie 151440 studentów uczelni prywatnych. Jednak w roku 2019 (nie ma jeszcze danych na 2020 rok), jest ich 341656 , co stanowi 28,38\% wszystkich studiujących w Polsce (patrz tabela 2). W trakcie boomu demograficznego, a więc w czasie, kiedy była najwyższa liczba studentów w Polsce, w latach 2004-2006 było to $32 \%$, a więc obecnie odsetek ten jest tylko niewiele mniejszy.

Natomiast sprawdza się prognoza Instytutu Sokratesa, że studenci zaoczni będą woleli studiować w szkołach prywatnych (Antonowicz, Gorlewski 2011: 21). Wśród wszystkich niestacjonarnych studentów w roku 2019 w uczelniach prywatnych kształci się 56,93\% studentów, wobec $43,07 \%$ studiujących na płatnych studiach uczelni państwowych (tabela 2). 
Tabela 2. Liczba studentów w roku 2019 w podziale na studia stacjonarne i niestacjonarne oraz publiczne i niepubliczne.

\begin{tabular}{llll} 
& & $\begin{array}{l}\text { Studia } \\
\text { stacjonarne }\end{array}$ & $\begin{array}{l}\text { Studia } \\
\text { niestacjonarne }\end{array}$ \\
\hline Liczba studentów & $1203998(100 \%)$ & $790688(65,7 \%)$ & $413310(34,3 \%)$ \\
\hline Uczelnie publiczne & $862342(71,62 \%)$ & $684313(83,55 \%)$ & $178029(43,07 \%)$ \\
\hline Uczelnie niepubliczne & $341656(28,38 \%)$ & $106375(13,45 \%)$ & $235281(56,93 \%)$ \\
\hline
\end{tabular}

Źródło: Opracowanie własne na podstawie: GUS 202b: 15

Trudno jest być prorokiem we własnym kraju, ale wydaje się, że szkolnictwo prywatne nie zamierza się poddawać niżowi demograficznemu, ani też wielu innym przeszkodom, z którymi musiało i musi się mierzyć w czasie ostatnich 30 lat. Przewaga studentów niestacjonarnych w tym sektorze była od początku widoczna. Być może będzie to główny obszar dalszej obecności i trwania tego sektora w szkolnictwie wyższym w Polsce. W ciągu ostatnich 10 lat, a więc w okresie niżu demograficznego, zamkniętych zostało stosunkowo niewiele uczelni prywatnych, ale też ciągle powstają nowe.

Uczelnie niepubliczne członkami Konferencji Rektorów Akademickich Szkół Polskich (KRASP)

W ostatniej części tego artykułu chciałabym wskazać na ukształtowaną w ciągu 30 lat w Polsce kategorię uczelni niepublicznych, które odniosły pewien sukces nie tylko w stosunku do pozostałych uczelni niepublicznych. Są to uczelnie, które w większości powstały w latach 90. XX wieku. Od dawna zajmują najwyższe miejsca w rankingach w kategorii szkół prywatnych: w latach 90. dwudziestego wieku w rankingu tygodnika 
„Wprost” (w pierwszym i wówczas jedynym rankingu szkół wyższych, który od wielu lat nie istnieje), następnie we wspólnym rankingu „Rzeczpospolitej” i „Perspektyw”, a obecnie w rankingu „Perspektyw”, a także, w zależności od specjalizacji, w innych rankingach, również międzynarodowych.

Są to uczelnie, które uzyskały status uczelni akademickich i mają uprawnienia do nadawania stopnia doktora, a niektóre z nich także doktora habilitowanego. Ponadto w dowód swojej pozycji zostały przyjęte do prestiżowej akademickiej organizacji - Konferencji Rektorów Akademickich Szkół Polskich. Obecnie członkami KRASP-u jest 10 uczelni prywatnych, ale jest też 5 uczelni, które czekają na przyjęcie i mają status uczelni stowarzyszonych w KRASP. Jedna z nich otrzymała już uprawnienia uniwersytetu, a kilka spełnia także warunki przysługujące akademiom i posługuje się tymi nazwami.

Wykazały się one nie tylko stosunkowo wysokim poziomem kształcenia studentów, ale te - co jest szczególnie ważne - statusem akademickim w postaci otrzymania wielu grantów badawczych w Polsce i zagranicą oraz znaczącym dorobkiem naukowym swoich wykładowców. Mają także stałą, wysokiej klasy kadrę wykładowców. Znaczna część programu realizowana jest w nich także w języku angielskim. W wielu kierunkach studiów uczelnie te są konkurencyjne w stosunku do uczelni publicznych. W ciągu ostatnich kilku lat, w okresie trudnego dla wszystkich uczelni niżu demograficznego, uczelnie te są częściej niż dawniej wybierane przez studentów, także jako uczelnie pierwszego wyboru. Od roku 2018, mimo niżu demograficznego, wzrasta nieco liczba studentów w uczelniach niepublicznych i - co szczególnie warte uwagi - na studiach stacjonarnych. W roku 2010 było ich 79 tys., w roku 2019 - 106 tys. (porównaj tabelę 1 i 2).

Można chyba założyć, że jednym z ważnych wskaźników dobrego poziomu nauczania w danej uczelni, poza rankingami (oraz wieloma innymi cechami), jest wysokość zarobków ich absolwentów. To pozwala ocenić przygotowanie studentów danej uczelni do funkcjonowania na 
rynku pracy w wielu wymiarach. Absolwenci, którzy otrzymali dyplomy ukończenia studiów w roku 2018 w 10. prywatnych uczelniach należących do KRASPu, po pierwszym roku pracy mają znacznie wyższe zarobki od studentów uczelni publicznych oraz uczelni prywatnych nie należących do KRASPu (poza kategorią absolwentów jednolitych studiów magisterskich, których absolwenci studiów stacjonarnych publicznych i prywatnych zarabiają podobnie). Średnia wysokość zarobków, po pierwszym roku studiów, absolwentów prywatnych uczelniach należących do KRASPu, a więc mających status uczelni akademickich, jest średnio o $1000 \mathrm{zł}$ wyższa od płacy absolwentów uczelni państwowych (patrz grafika 1).

Grafika 1. Zarobki brutto w 1 roku po dyplomie

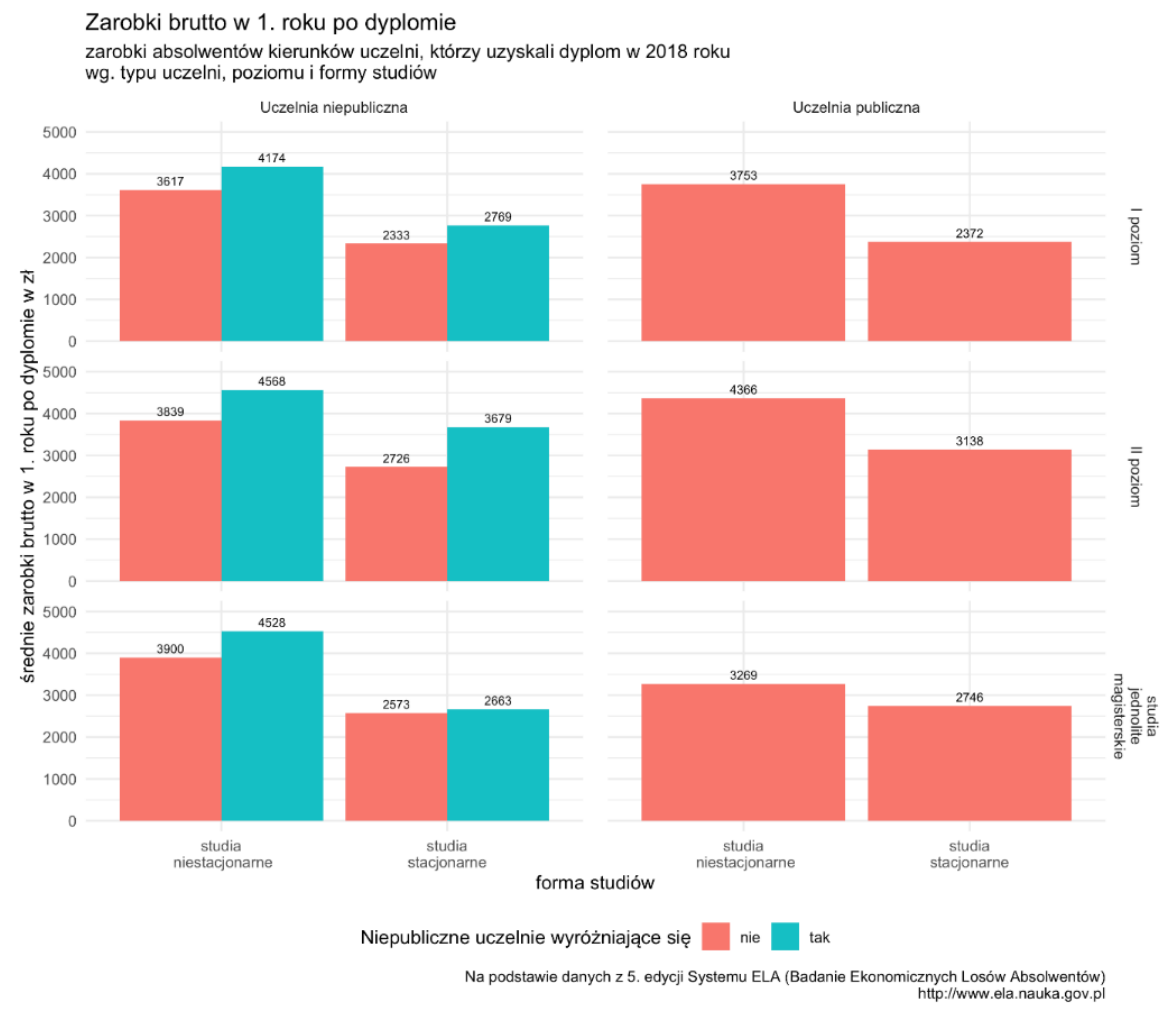

Źródło: Opracowanie dr Jacek Bieliński: Ośrodek Przetwarzania Informacji - Państwowy Instytut Badawczy. 
Wydaje się, że grupa 10 uczelni, które wyodrębniono na podstawie ich członkostwa w KRASP-ie, może być zaliczana do kategorii semi-elites szkół prywatnych, którą wyszczególnił i zdefiniował w swoich pracach nad prywatnym szkolnictwem wyższym w różnych częściach świata Daniel C. Levy (2006) - wybitny znawca i badacz procesów prywatyzacji szkolnictwa wyższego w Europie Środkowo-Wschodniej. Obecnie jest to jedynie hipoteza. Kilkanaście lat temu doktorantka profesora Leve'go prowadziła dla celów swojej pracy doktorskiej badania nad semi-elites szkół wyższych w Polsce (Musiał 2012). Wówczas zbadane przez nią uczelnie wybrane na podstawie wysokiej pozycji w rankingach szkół wyższych w znacznym stopniu spełniały kryteria wyznaczone przez Levy'ego. W najbliższych latach warto byłoby takie badania powtórzyć.

Uczelnie należące do KRASP-u mają status uczelni akademickich, ich absolwenci dobrze zarabiają (relatywnie w stosunku do innych uczelni publicznych i prywatnych), co oznacza, że dobrze funkcjonują na rynku pracy. Uczelnie te mają międzynarodowe certyfikaty i, co może najważniejsze, w okresie niżu demograficznego nie zmniejszają, a zwiększają liczbę nowoprzyjętych studentów. Niestety, nie ma jeszcze dokładnych informacji na temat wyników rekrutacji na tych 10 uczelniach w roku 2020. Informacje o dobrych, a nawet lepszych niż w poprzednich latach wynikach pochodzą z mediów, od dziennikarzy, którzy przeprowadzili wywiady z rektorami tych uczelni.

Portal money.pl opublikował artykuł pod tytułem $W$ Polsce mamy boom na prywatne uczelnie. Zanotowano rekordowy - ponad dwucyfrowy wzrost (b.a. 2019). Natomiast tekst opublikowany przez Polską Agencję Prasową zaczyna się tak: „Liczba studentów na wiodących polskich uczelniach niepublicznych - wbrew wcześniejszym obawom ich władz - utrzymuje się na podobnym poziomie. Niektóre uczelnie odnotowały nawet większe zainteresowanie w czasie obecnej rekrutacji niż w latach poprzednich" (Zdziebłowski 2020). Mam nadzieję, że nie jest to autoreklama rektorów uczelni, których wypowiedzi są cytowane przez dziennikarza. 
Wydaje się, że niż demograficzny wpływa negatywnie na szkolnictwo prywatne w Polsce, które utrzymuje się jedynie z czesnego. Jednak tych zmian, które nastąpiły w przeciągu 14 lat, zdecydowanie nie można nazwać tsunami czy deprywatyzacją szkolnictwa wyższego w Polsce. Zmniejszenie się liczby studentów w uczelniach niepublicznych jest znacznie mniejsze niż przewidywano. Nie zmniejszyła się też dramatycznie liczba uczelni prywatnych. Zwiększył się proporcjonalnie w tych uczelniach odsetek studentów niestacjonarnych. Wydaje się, że studia niestacjonarne będą znaczącą i dość stabilną domeną uczelni prywatnych. Studenci tych uczelni dobrze sobie radzą na rynku pracy. Duch innowacji, konkurencji i przetrwania zdaje się być ciągle obecny wśród kadry zarządzającej w tych uczelniach.

Wydaje się też, że 15 uczelni (członkowie i stowarzyszeni w KRASP) staje się coraz bardziej rozpoznawalnych na rynku edukacyjnym. Uczelnie te podwyższają reputację wyższego szkolnictwa prywatnego wobec wielu negatywnych przykładów i niskiego poziomu nauczania niektórych uczelni prywatnych. Czy można założyć, że te najsłabsze uczelnie, uczące na bardzo niskim poziomie, znikną z przestrzeni szkolnictwa wyższego w Polsce? Trudno to przewidzieć.

\section{Literatura}

(b.a.) (2019). W Polsce mamy boom na prywatne uczelnie. Zanotowano rekordowy - ponad dwucyfrowy wzrost. Portal money.pl, https://www.money.pl/gospodarka/w-polsce-mamy-boom-na-prywatne-uczelnie-zanotowano-rekordowy-ponad-dwucyfrowy-wzrost6437472160557185a.html.

Altbach, P.G., Reisberg, L., Rumbley, L.E. (2009). Trends in global higher education: Tracking an academic revolution. Executive Summary. 
A Report Prepared for the UNESCO 2009 World Conference on Higher Education. Paris: UNESCO.

Antonowicz, D., Gorlewski, B. (2011). Demograficzne tsunami. Raport Instytutu Sokratesa na temat wphywu zmian demograficznych na szkolnictwo wyższe do 2020 roku. Warszawa: Instytut Sokratesa. ASHE Higher Education Report. (2010). Special Issue: The Global Growth of Private Higher Education, Vol. 36, No. 3.

Bajerski, A. (2007). Prywatne szkolnictwo wyższe w Republice Czeskiej. Nauka i Szkolnictwo Wyższe nr 2(30). 94-103.

Balcerowicz, L. (2002). Post-communist transition. London: Institute of Economic Affairs.

Białecki, I. (2008). Międzynarodowe badania, debata, polityka edukacyjna. Nauka i Szkolnictwo Wyższe nr 1/31. 22-33.

Bjarnason, S., Cheng, K.-M., Fieldon, J., Lamaitre, M.-J., Levy, D.C., Varghese, N.Y. (2009). A new dynamic: Private Higher Education. World conference on higher education. Paris: UNESCO.

Bourdieu, P., Passeron, J.C. (1990). Reproduction in education, society and culture. London: Sage.

Clark, B. (1998). Creating entrepreneurial universities: Organizational pathways of transformation. Oxford: International Association of Universities and Elsevier Science.

Deem, R. (2001). Globalization, new managerialism, academic capitalism and enterpreneurialism in universities: Is the local dimension still important? Comparative Education 37(1). 7-20.

Duchmal, W. (2006). The rise of private higher education in Poland: Policies, markets and strategies. Enschede: University of Twente.

Duszyński, J., Burczyński, T., Rowiński, P.M., Rychard, A. (2017). Projekt: Uniwersytet PAN. Nauka i Szkolnictwo Wyższe, nr 2(50). 5976. https://doi.org/10.14746/nisw.2017.2.2.

Enterpreneurialism in universities and the knowledge economy. (2008). (Ed.) Shattock, M. Maidenhead, New York: Open University Press, McGraw-Hill. 
Edquist, Ch., Fulton, O., Santiago, P., El-Khawas, E., Hackle, E. (2007). Thematic Review of Tertiary Education: Poland. Paris: Organization for Economic Co-operation and Development, Directorate for Education, Education and Training Policy Division

Geiger, R. (1986). Private sectors in higher education: Structure, function and change in eight countries. Ann Arbor, MI: University of Michigan Press.

GUS. (2020a). Struktura ludności według wieku od 1970 r. https://stat. gov.pl/obszary-tematyczne/ludnosc/ludnosc/ludnosc-piramida/.

GUS. (2020b). Szkolnictwo wyższe $i$ jego finanse w 2019 roku. https://stat.gov.pl/obszary-tematyczne/edukacja/edukacja/szkolnictwo-wyzsze-i-jego-finanse-w-2019-roku,2,16.html.

Jamshidi, L., Arasteh, H., Naveh, E.A., Zeinabadi, H., Rasmussen, P.D. (2012). Development patterns of privatization in higher education: A comparative study. Higher Education, Vol. 64, 789-803.

Kinser, K. at al. (2010). The Global Growth of Private Higher Education. ASHE Higher Education Report Vol. 36, No. 3. 1-158.

Koralewicz, J. (2012). Można. Warszawa: Collegium Civitas Press.

Koralewicz, J., Ziółkowski, M. (2003). Mentalność Polaków. Warszawa: Wydawnictwo Naukowe Scholar i Collegium Civitas Press.

Koralewicz, J., Ziółkowski, M. (2006). Changing value system. [w:] New Europe. The impact of the first decade, Vol. 1, Trends and Prospects. (Eds.) Rakowska-Harmstone, T., Dutkiewicz, P. Warszawa: Instytut Studiów Politycznych PAN. 177-206.

Kwiek, M. (2009). The two decades of privatization in Polish higher education. Cost-sharing equity and access. [w:] Financing higher education: Equity and access. (Ed.) Knight, J. Rotterdam-Tajpej: Sense Publishers. 149-168.

Kwiek, M. (2011). Creeping marketization: Where Polish private and public higher education sectors meet. [w:] Higher education and the market. (Ed.) Brown, R. New York: Routledge. 135-145. 
Kwiek, M. (2015). Uniwersytet $w$ dobie przemian. Warszawa: Wydawnictwo Naukowe PWN.

Levy, D.C. (1986). "Private" and "public": Analysis amid ambiguity in higher education. [w:] Private education: Studies in choice and public policy. (Ed.) Levy, D.C. Oxford, New York: Oxford University Press.

Levy, D.C. (2006). The unanticipated explosion: Private higher education's global surge. Comparative Education Review 50(2), 217-239.

Levy, D.C. (2012). How important is private higher education in Europe? A regional analysis. European Journal of Education. Special Issue: The Privatisation of Higher Education 47(2), 178-197.

MEiN. (2020). Wykaz uczelni niepublicznych, https://www.gov.pl/ web/edukacja-i-nauka/wykaz-uczelni-niepublicznych.

MNiSW. (2013). Szkolnictwo wyższe w Polsce. Warszawa: Ministerstwo Nauki i Szkolnictwa Wyższego.

Mok, K.H. (2009). The growing importance of the privateness in education: Challenges for higher education governance in China. A Journal of Comparative \& International Education, Vol. 39, No. 1, 35-49.

Musiał, J. (2012). Typical and Top-ranked Polish Private Higher Education: Intersectoral and Intrasectoral Distinctiveness. A Disseration Submitted to the University at Albany, State University of New York. School of Education Department of Education Administration and Policy Studies. Albany: State University of New York at Albany

Nicolescu, L. (2007). Institutional efforts for legislative recognition and market acceptance: Romanian private higher education. [w:] Private higher education in post-communist Europe. (2007). (Ed.) Slantcheva, S., Levy, D.C. New York: Palgrave Macmillan. 201-222. Ośrodek Przetwarzania Informacji - Państwowy Instytut Badawczy. (2019). Szkolnictwo wyższe $w$ Polsce $w$ latach 2012-2018. Raport opracowany na zlecenie MNiSW, Warszawa.

Pachuashvili, M. (2009). The politics of higher education: Governmental policy choices and private higher education in post-communist countries. A comparative study of Hungary, Georgia, Latvia and 
Lithuania. Doctoral Dissertation. Budapest: Department of Political Science. Central European University.

Private higher education: A global revolution. (2005). (Eds.) Altbach, P.G., Levy, D.C. Rotterdam: Sense Publishers.

Private higher education in post-communist Europe. (2007). (Eds.)

Slantcheva, S., Levy, D.C. New York: Palgrave Macmillan.

Rabossi, M.A. (2011). Differences between public and private universities' field of study in Argentina. Higher Education Management and Policy, Vol. 23, Iss. 1. 1-19. DOI: https://dx.doi.org/10.1787/hemp23-5kgglbdlpdot.

Scott, P. (2007). Higher education in central and eastern Europe. [w:] International handbook of higher education. Part II. (Eds.) Forest J.J.F., Altbach, P.G. New York: Springer. 423-441.

Strategia Rozwoju Szkolnictwa Wyższego w Polsce do 2020 roku. (2010). Warszawa: Ernst \& Young Business Advisory, Instytut Badań nad Gospodarką Rynkową. http://uczelnie2020.pl/o-projekcie/

Suspitsin, D. (2005). Russian private higher education: Aliances with state-run organizations. [w:] Private higher education: A global revolution. (Eds.) Altbach, P., Levy, D.C. Rotterdam: Sense Publishers.

Tomusk, V. (2003). The war of institutions, Episode I: The rise, and the rise of private higher education in eastern Europe. Higher Education Policy Vol. 16, 213-238.

Ustawa. (1990). Ustawa z dnia 12 września 1990 r. o szkolnictwie wyższym, Dz.U. 1990 nr 65 poz. 385. http://isap.sejm.gov.pl/isap.nsf/ DocDetails.xsp?id=WDU19900650385\&SessionID=07A732157FC9 1A9B7EC217000E54AB44AC54346.

Ustawa. (2018). Ustawa z dnia 20 lipca 2018 r. - Prawo o szkolnictwie wyższym i nauce, Dz.U. 2018 poz. 1668. https://isap.sejm.gov.pl/ isap.nsf/DocDetails.xsp?id=WDU20180001668.

Welch, A.R. (2007). Blurred vision?: Public and private higher education in Indonesia. Higher Education Vol. 54, No. 5, 665-687. 
Wells, P.J., Sadlak, J., Vlasceanu, L. (2007). The rising role and relevance of private higher education in Europe. Bucharest: UNESCO-CEPES.

World Bank. (2004). Tertiary education in Poland. Washington, DC: World Bank.

Zawistowska, A. (2012). Horyzontalne nierówności we wspótczesnej Polsce. Warszawa: Wydawnictwo Naukowe Scholar.

Zakowicz, I. (2013). Uniwersytet - przedsiębiorstwo produkcyjnoustugowe, student - klient supermarketu? Czyli szkolnictwo wyższe w procesie zmian. [w:] Fabryka dyplomów czy universitas? O,nadwiślańskiej” wersji przemian w edukacji akademickiej. (red. nauk.) Czerepaniak-Walczak, M., Kraków: Oficyna Wydawnicza „Impuls”. Zdziebłowski, S. (2020). Wiodace uczelnie niepubliczne: wbrew obawom liczba studentów na podobnym poziomie, PAP - Nauka w Polsce, https://naukawpolsce.pap.pl/aktualnosci/news\%2C84134\%2C wiodace-uczelnie-niepubliczne-wbrew-obawom-liczba-studentowna-podobnym. 